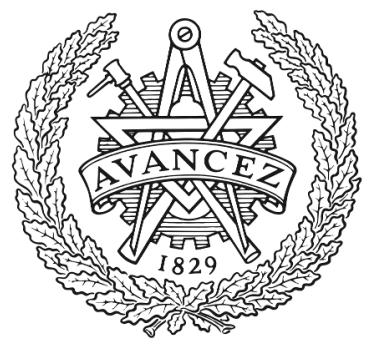

CHALMERS

UNIVERSITY OF TECHNOLOGY

\title{
Multi-criteria decision analysis methods to support sustainable infrastructure construction
}

Downloaded from: https://research.chalmers.se, 2023-04-26 09:08 UTC

Citation for the original published paper (version of record):

Ek, K., Mathern, A., Rempling, R. et al (2019). Multi-criteria decision analysis methods to support sustainable infrastructure construction. IABSE Symposium, Guimaraes 2019: Towards a Resilient Built Environment Risk and Asset Management - Report: 1084-1091

N.B. When citing this work, cite the original published paper. 


\title{
Multi-criteria decision analysis methods to support sustainable infrastructure construction
}

\author{
Kristine Ek, Alexandre Mathern, Rasmus Rempling, Lars Rosén, Christina Claeson-Jonsson
}

Chalmers University of Technology, Sweden

Petra Brinkhoff, Malin Norin

NCC AB, Sweden

Contacting author: kristine.ek@chalmers.se

\begin{abstract}
The construction of infrastructure projects represents a large sustainability impact, both positive and negative. Increased positive and reduced negative impacts can be achieved through better design and planning of the construction. To make more sustainable choices, well-defined predictive sustainability assessment methods are required. Multi-criteria decision analysis (MCDA) is a wellsuited method for predictive sustainability assessment. This paper evaluates two MCDA methods for sustainability assessment of infrastructure construction and exemplifies their application with two case studies. The aim of this paper is to discuss if the methods are suitable for identifying the most sustainable alternative during the procurement process of an infrastructure project. It is recommended that MCDA methods are further developed to comply with the recently published EN standard on sustainability assessment of civil engineering works.
\end{abstract}

Keywords: Sustainability assessment; life cycle assessment; infrastructure; multi-criteria decision analysis; key performance criteria; case study; design; planning.

\section{Introduction}

Civil infrastructure projects represent a large sustainability impact during construction [1]. The impact can be reduced through better design and planning [2]. To make sustainable choices in these stages, well-defined predictive sustainability assessment methods are required [3].

Multi-criteria decision analysis (MCDA) is a method which takes into account multiple criteria to help decision makers organise information in order to make a confident decision [4]. It is a well-suited method for predictive sustainability assessment and has often been used for this purpose [5-8]. MCDA can be used in different project stages; in the client's design, in procurement and in the contractor's production planning, or for follow-up. In the procurement stage, MCDA methods can be used to evaluate tenders. However, this sets high requirements on the method and the process used for the evaluation. Because of this, clients procuring infrastructure projects almost always base the choice on the lowest price quotation from the contractor according to detailed specifications drawn up by the client. This traditional tender procedure therefore constitutes one of the most important barriers to achieve sustainable projects.

However, EU directive 2014/24/EU, which describes the procedures for public works procurement, specifies that the award of contract must be based on the 'most economically advantageous tender' to the authority (MEAT) [9]. 
This can include assessments based on price only, as well as other methods including the 'best price/quality ratio', which can include social and environmental requirements provided they relate to the contract. Social aspects can be considered in certain circumstances in addition to environmental aspects. Contracting authorities can require certification, labels or other equivalent evidence, further facilitating procurement of contracts with social and environmental objectives. Contracting authorities may specify production processes and methods regarding social and environmental issues. The full life-cycle costing can also be considered when awarding contracts.

An example of a contracting authority considering environmental aspects in procurement is the Swedish Transport Agency. Since 2015, they require a climate calculation and declaration for all investment projects and climate reduction measures to be taken [10]. The climate declaration is a single-issue LCA tool considering global warming potential (GWP). If the contractor succeeds to meet the climate impact reduction goals based on this declaration, they receive a bonus. A fine may be issued if the Swedish Transport Agency is judged to be harmed because the climate performance is not reached.

This paper presents two MCDA methods for sustainability assessment of infrastructure construction in the procurement stage and exemplifies their application with case studies. The aim of this paper is to discuss if the methods are suitable for choosing the most sustainable project alternative in the procurement stage of infrastructure projects.

\section{Background}

The MCDA methods described in this paper were used to evaluate the sustainability of project alternatives during the procurement stage of an infrastructure project. These methods are just a few of many MCDA methods available, for example, for site remediation alternatives [5], for infrastructure management [11] and for product design and development options [6, 7]. MCDA methods are best suited to use early in turnkey contracts or in partnering projects because in these cases there are greater possibilities to make changes in the project.

A MCDA method used in the procurement stage should satisfy the following characteristics [12]:

- Flexibility: The method should be usable with different sets of criteria and for diverse projects with minor adjustments.

- Consistency: The results of the assessment should be coherent and reproducible with low variation.

- Transparency: The method needs to be predefined and described in the tender documents. The way the results are obtained should be transparent.

- Measurability and controllability: The assessment should be based on measurable and controllable information provided by the contractor. Thereby, the contracting authority can control if the performance level announced in the tender has been satisfied.

An example of a set of Key Performance Criteria (KPCs) to use in the procurement stage for civil and infrastructure projects is given in "Think ahead" [13], see Table 1.

Table 1. KPCs in "Think ahead".

\begin{tabular}{|c|c|c|}
\hline $\begin{array}{l}\text { Environmental } \\
\text { domain }\end{array}$ & Social domain & $\begin{array}{l}\text { Economic } \\
\text { domain }\end{array}$ \\
\hline $\begin{array}{l}\text { Effects of } \\
\text { climate change } \\
\text { Ecosystem/ } \\
\text { Biological } \\
\text { diversity } \\
\text { Water and soil } \\
\text { quality } \\
\text { Resource } \\
\text { strategy \& use } \\
\text { Waste } \\
\text { Air incl. } \mathrm{CO}_{2} \\
\text { emissions } \\
\text { Transport }\end{array}$ & $\begin{array}{l}\text { Internal/ } \\
\text { external } \\
\text { communication } \\
\text { Cultural } \\
\text { heritage } \\
\text { Equality } \\
\text { Local } \\
\text { participation } \\
\text { Health \& safety } \\
\text { Local } \\
\text { environmental } \\
\text { quality \& } \\
\text { amenity }\end{array}$ & $\begin{array}{l}\text { Sustainability } \\
\text { strategy and } \\
\text { management } \\
\text { Project } \\
\text { strategy and } \\
\text { management } \\
\text { Production } \\
\text { strategy and } \\
\text { management }\end{array}$ \\
\hline
\end{tabular}

The KPCS were developed based on the sustainability aspects in the sustainability rating system CEEQUAL [14]. CEEQUAL is established rating system that has been used for more than fifteen years and was originally developed by sustainability and technical experts. For each KPC a 
comprehensive description was created based on the questions in the CEEQUAL assessment manual. A fully-developed MCDA method was not created in "Think ahead", but it provides a basis for later use in a MCDA method to be used by contractors and designers in design and production planning.

Once criteria are set, the way they will be assessed must be defined in tender documents [12]. The client should communicate the method of assessment to the contractors in good time, so that they can take it into account when preparing the tenders. Weighting of the criteria and their focus is also essential knowledge for the contractors to be able to propose alternative and innovative solutions. The weighting does not only depend on the specifics of a project but also on the policy of the client.

Since late 2017, there is an EN standard on sustainability assessment of buildings and civil engineering works, providing a framework on specific principles and requirements for the assessment [15]. The standard highlights that assessment methods shall be credible, transparent and systematic to achieve verifiability, transparency and comparability in the results of the assessment. It also states that the assessment shall determine impacts and aspects (the loads and benefits) related to the asset itself, the area of influence and the additional functions provided by the asset, in addition to its primary function. The standard further requires that sustainability assessments include all stages of the construction works life cycle; the before use stage (including the pre-construction stage), the use stage, the end of life stage, and the benefits and loads beyond the system boundary. Comparisons between similar projects is to be made based on a functional equivalence.

\section{Method}

Two MCDA methods; "Sustainable Choice Of Remediation" (SCORE) [16] and a sustainability assessment method for bridge projects based on the KPCs developed in the EU FP7 project PANTURA (hereafter called the PANTURA method) $[12,17]$, are exemplified in two case studies.

These MCDA methods were selected for the case studies since they are based on a weighted scoring approach, facilitating a clear and transparent procedure where effects are represented by scorings and valuation of criteria importance are represented by weightings.

\subsection{SCORE}

SCORE provides a transparent assessment of the sustainability of possible remediation alternatives for contaminated sites relative to a reference alternative. In SCORE, the expected effects of alternatives are represented by scorings in the environmental and social domains and quantifications of monetary costs and benefits in the economic domain. A normalized score is calculated for each alternative using a linear additive approach, considering scorings and quantifications of the KPC and the relative importance (weights) of these KPC. An uncertainty is assigned to each scoring and quantification, facilitating uncertainty and sensitivity analyses of the outcomes. SCORE also identifies possibilities to improve the sustainability of studied alternatives. Thus, the method has an iterative approach, encouraging updating as new information becomes available. The KPCs used in the SCORE methodology are listed in Table 2.

Table 2. KPCs used in SCORE.

\begin{tabular}{lll}
\hline $\begin{array}{l}\text { Environmental } \\
\text { domain }\end{array}$ & Social domain & $\begin{array}{l}\text { Economic } \\
\text { domain }\end{array}$ \\
\hline $\begin{array}{l}\text { Soil } \\
\text { Flora and fauna }\end{array}$ & $\begin{array}{l}\text { Local } \\
\text { environmental } \\
\text { Groundwater }\end{array}$ & $\begin{array}{l}\text { Social } \\
\text { profitability and } \\
\text { amenity }\end{array}$ \\
$\begin{array}{l}\text { Sediment } \\
\text { Air }\end{array}$ & $\begin{array}{l}\text { Cultural heritage } \\
\text { Eon-renewable }\end{array}$ & Health and safety \\
natural & Local & \\
resources & participation & \\
Non-recyclable & Local acceptance & \\
waste & & \\
\hline
\end{tabular}

The KPCs in the social domain have sub-criteria representing on-site and off-site effects as well as effects related to the change in source contamination (SC) and the remedial action (RA), respectively. The KPC in the economic domain is social profitability assessed by means of costbenefit analysis (CBA). The social profitability is 
calculated in monetary terms as a net present value (NPV) over the time horizon of the remediation project.

The SCORE assessment starts by selecting relevant KPCs and sub-criteria for the analysis. In the case that criteria or cost-benefit items are chosen to be excluded from the assessment, a clear motivation should be provided.

Scoring of KPCs in the environmental and social domains is performed using the semi-quantitative (ordinal) performance scale from +10 to -10 , where the first represents a very positive effect and the later a very negative effect compared to the reference alternative (no action). The scorings are performed using available data, expert judgment, questionnaires, and/or individual or group interviews. The scoring procedure is supported by a guidance matrix for each KPC. The assessment team shall assign the score that best represents the expected effect, given the available information and knowledge. Each scoring must be shortly motivated.

Each KPC and sub-criterion in the environmental and social domains is weighted with respect to its relative importance. The importance I of each KPC $k$ in domain $D$ is given a numerical value according to the following scale: somewhat important $=1$; important $=2$; very important $=3$. The weight of the KPC is calculated as:

$$
w_{k, D}=\frac{I_{k, D}}{\sum_{k=1}^{K} I_{k, D}}
$$

The importance I of each sub-criterion $j$ included in KPC $k$ is given a numerical value according to the following scale: somewhat important $=1$; important $=2$; very important $=3$. The weight of each sub-criterion is calculated as:

$$
w_{j, k}=\frac{I_{j, k}}{\sum_{j=1}^{J} I_{j, k}}
$$

The weights of sub-criteria and KPCs thus have a value between 0 and 1 and the total weight of all KPCs (sub-criteria and KPCs, respectively) sums to 1.
For each remediation alternative $i$, a sustainability index $H$ is calculated for the environmental and social domain $D$, respectively, as the weighted sum of the scorings using a linear additive approach:

$$
H_{D, i}=\sum_{k=1}^{K} w_{k, D} \sum_{j=1}^{J} w_{j, k, D} Z_{j, k, D}
$$

where $w_{j}$ is the weight of sub-criterion $j$ and $Z$ is the score of the sub-criterion $j$. The weighting is performed by the assessment team, taking judgments and opinions of experts and stakeholders into consideration.

In the economic domain, cost and benefit items of the CBA are monetized to the greatest extent possible. All items identified as relevant but not possible to monetize are assessed as being somewhat important or very important, allowing for a qualitative assessment of these items and the outcomes of the CBA. Weighting of benefits and costs is carried out through the monetization in the NPV calculation.

A normalized sustainability score, $H$, is calculated for each alternative $i$ as:

$H_{i}=100\left[W_{E} \frac{H_{E, i}}{\max \left(\left|H_{E, 1 . N}\right|\right)}+W_{S} \frac{H_{S, i}}{\max \left(\left|H_{S, 1 . N}\right|\right)}+\right.$

$\left.W_{N P V} \frac{N P V_{i}}{\max \left(\left|N P V_{1 . . N}\right|\right)}\right]$

where $H_{E}$ is the score in the environmental domain, $H_{s}$ is the score in the social domain, NPV is the net present value, and $W$ is the weight of each domain. The weights of the domains are assigned according to the same scale as for the KPCs. The normalized score has a value between -100 and +100 , where a positive score indicates that the alternative leads towards sustainable development, i.e. more positive effects than negative.

The normalized score provides a relative ranking of the analysed alternatives. The absolute value of the normalized score of an alternative is dependent on the scorings of other alternatives included in the assessment. Thus, SCORE provides a sustainability assessment on the local scale and scores for one project cannot be compared to scores for another project. Ranking and final selection are then made among alternatives that meet the sustainability 
definition. A major advantage of SCORE is that it clearly identifies which KPC should be improved to meet a specific definition of sustainability.

\subsection{PANTURA method}

The PANTURA method is a performance-based procurement method for urban infrastructure projects. The method is based on MEAT for lowdisturbance bridge construction projects in an urban environment. It has been shown that this kind of method can be implemented both in traditional (design-bid-build) and in integrated (design-and-build) procurement [17].

The client starts by defining the KPC that should be considered for the project from the set of available KPC, see Table 3. To do so it is useful to recognize the aim of including certain KPC in the evaluation of tenders. KPCS were developed specifically for sustainability assessment of bridge construction sites in urban environments. The social KPCs consider effects during the construction phase onsite or close to the site.

Table 3. KPCs used in the PANTURA method.

\begin{tabular}{|c|c|c|}
\hline $\begin{array}{l}\text { Environmental } \\
\text { domain }\end{array}$ & Social domain & $\begin{array}{l}\text { Economic } \\
\text { domain }\end{array}$ \\
\hline \multirow{6}{*}{$\begin{array}{l}\text { GWP (in the } \\
\text { construction } \\
\text { phase) }\end{array}$} & Dust emissions & Purchase price \\
\hline & Safety of workers & Life cycle cost \\
\hline & Safety of road users & \\
\hline & Mobility & \\
\hline & Noise and vibration & \\
\hline & $\begin{array}{l}\text { Total time of } \\
\text { construction on-site }\end{array}$ & \\
\hline
\end{tabular}

To calculate scores, the different quantities given for each $\mathrm{KPC}, Z_{C}$, are first converted to normalized scores for the KPC, $H_{C}$. $H_{C}$ has a positive value if it is considered as a positive impact on the KPC and a negative value if it is considered as a negative impact on the KPC. There are different methods to normalize the scores. One is relative normalization, where the quantity of alternative $i$ is divided by the sum of the quantity of all $n$ alternatives. For each KPC $C$ of each alternative $i$, a normalized sustainability score, $H_{c, i}$, is calculated as:

$$
H_{C, i}=100 \frac{Z_{C, i}}{\sum_{i=1}^{n} Z_{C, i}}
$$

Weighted scores are then obtained by multiplying the normalized sustainability score for each KPC of each alternative, $H_{c, i}$, by the weight of the KPC, $w_{c}$. The total score for alternative $i, H_{i}$, is the sum of the weighted scores of the $m$ KPCs.

$$
H_{i}=\sum_{C=1}^{m} w_{C} H_{C, i}
$$

\section{Case studies}

\subsection{Norsholm (SCORE method)}

The first case study is a sustainability assessment of two alternative tenders for a ground stabilization project. The alternatives were stabilization with either (1) cement piles or (2) wood piles. The wood piles would be installed using a caterpillar excavator and then vibrated into the ground. The cement piles would be made using the WET-mixing method.

In the case study, the SCORE methodology is used as a basis with some alterations. In the environmental domain, the only KPC used is GWP, calculated with life cycle assessment (LCA). Only GWP was included because this was the KPC of most interest for the client. The score range of the social domain used in the case study also has a narrower range compared to the SCORE method; from -3 to +3 . This was because the information available was relatively limited.

The sustainability assessment was performed by combining cost-benefit analysis, social assessment and LCA considering GWP. The LCA for the case study was performed according to relevant standards [18-21], for modules A1-A5 in accordance with the EN15804 standard. The KPC used in the case study are listed in Table 4. Table 5 presents the calculated normalized and weighted scores. 
Table 4. KPCs chosen for the Norsholm case study.

\begin{tabular}{lll}
\hline $\begin{array}{l}\text { Environmental } \\
\text { domain }\end{array}$ & Social domain & $\begin{array}{l}\text { Economic } \\
\text { domain }\end{array}$ \\
\hline GWP & $\begin{array}{l}\text { Local } \\
\text { environmental } \\
\text { quality and } \\
\text { amenity }\end{array}$ & $\begin{array}{l}\text { Social } \\
\text { profitability }\end{array}$ \\
& Cultural heritage & \\
& Health \& safety & \\
& Local & \\
& participation & \\
&
\end{tabular}

Table 5. Quantities and calculated normalized and weighted scores for each KPC in the Norsholm case study.

\begin{tabular}{|c|c|c|c|c|c|c|c|}
\hline & \multirow{2}{*}{\begin{tabular}{|l|}
$\begin{array}{l}\text { Environ- } \\
\text { mental }\end{array}$ \\
\\
\\
迩
\end{tabular}} & \multicolumn{4}{|c|}{ Social } & \multirow{2}{*}{$\begin{array}{l}\text { Eco- } \\
\text { nomic }\end{array}$} & \multirow[b]{2}{*}{ 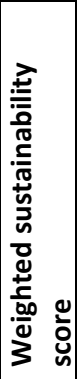 } \\
\hline & & 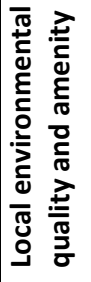 & 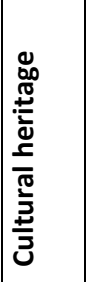 & 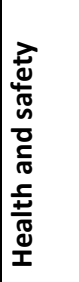 & 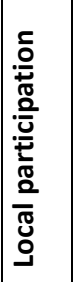 & & \\
\hline Weight & 0,33 & 0,0825 & 0,0825 & 0,099 & 0,066 & 0,33 & - \\
\hline Alternative 1 & $\begin{array}{c}7786 \\
\text { ton } \mathrm{CO}_{2} \mathrm{e} \\
\end{array}$ & 0 & 1 & $-1,7$ & 0 & \begin{tabular}{|l|}
$-24,5$ \\
MSEK \\
\end{tabular} & - \\
\hline $\begin{array}{l}\text { Normalized } \\
\text { score }\end{array}$ & -100 & \multicolumn{4}{|c|}{$-18,5$} & -100 & - \\
\hline $\begin{array}{l}\text { Weighted } \\
\text { score }\end{array}$ & $-33,3$ & \multicolumn{4}{|c|}{$-6,2$} & $-33,3$ & $-72,8$ \\
\hline Alternative 2 & $\begin{array}{c}214 \\
\text { ton } \mathrm{CO}_{2} \mathrm{e}\end{array}$ & 1,5 & 3 & $-0,4$ & 2 & $\begin{array}{l}-16,8 \\
\text { MSEK }\end{array}$ & - \\
\hline $\begin{array}{l}\text { Normalized } \\
\text { score }\end{array}$ & $-2,7$ & \multicolumn{4}{|c|}{100} & $-68,6$ & - \\
\hline $\begin{array}{l}\text { Weighted } \\
\text { score }\end{array}$ & $-0,9$ & \multicolumn{4}{|c|}{33,3} & $-22,9$ & 9,6 \\
\hline
\end{tabular}

The assessment shows that alternative 2 has the best potential to contribute to a sustainable development.

\subsection{Rotebro (PANTURA method)}

The second case study is a sustainability assessment of two alternative tenders for a project where two parallel concrete bridges were replaced by steel-concrete composite bridges. The alternatives were (1) using a temporary steel bridge during the construction time, or (2) building one of the new bridges beside the old ones and using it as a temporary bridge during construction and sliding it laterally into its permanent position afterwards.

Due to the complexity of the project, the client the Swedish Transport Administration - used the design-and-build project delivery strategy. The tender invitation encouraged the tenderers to propose innovative solutions and allowed them to submit alternative tenders. The tenders were to be evaluated primarily based on price, but a bonus would be given to the contractor if the construction period could be shorter than foreseen by the client.

The sustainability assessment was performed by the contractor, considering the most important KPCs to be the construction costs (including design costs), followed by mobility, the total time of construction on-site, the environmental impact, and the generation of noise and vibrations (see Table 6).

Table 6. KPCs chosen for the Rotebro case study.

\begin{tabular}{lll}
\hline $\begin{array}{l}\text { Environmental } \\
\text { domain }\end{array}$ & $\begin{array}{l}\text { Social } \\
\text { domain }\end{array}$ & $\begin{array}{l}\text { Economic } \\
\text { domain }\end{array}$ \\
\hline GWP & $\begin{array}{l}\text { Time of } \\
\text { construction }\end{array}$ & $\begin{array}{l}\text { Construction } \\
\text { costs }\end{array}$ \\
& $\begin{array}{l}\text { Noise and } \\
\text { vibrations }\end{array}$ & $\begin{array}{l}\text { Traffic delay } \\
\text { costs }\end{array}$ \\
\hline
\end{tabular}

Based on available information and experience, the weighting of the KPCs for the Rotebro project was set as given in Table 7. The information available in the procurement stage were the estimated construction costs, the number of available lanes during construction, the days of activities causing noise and vibrations, and the time of construction. A LCA was conducted to calculate the GWP for each alternative, based on the contractor's calculations for the two tenders. Scores were normalized using relative normalization, described in chapter 3.2. The normalized and weighted scores for the Rotebro project are presented in Table 7. 
Table 7. Quantities and calculated normalized and weighted scores for each KPC in the Rotebro case study.

\begin{tabular}{|c|c|c|c|c|c|c|}
\hline & 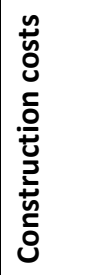 & 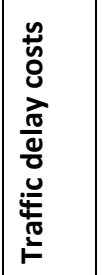 & 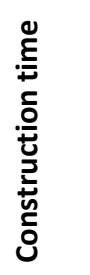 & 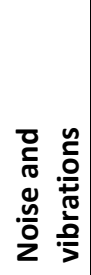 & 产 & 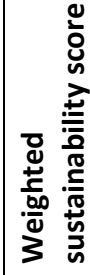 \\
\hline Weight [\%] & 80 & 7 & 6 & 2 & 5 & - \\
\hline Alternative 1 & $\begin{array}{c}355 \\
\text { MSEK }\end{array}$ & $\begin{array}{c}51.6 \\
\text { MSEK }\end{array}$ & $\begin{array}{l}1095 \\
\text { days }\end{array}$ & $\begin{array}{l}483 \\
\text { days }\end{array}$ & $\left|\begin{array}{c}18 \mathrm{100} \\
\text { ton } \\
\mathrm{CO}_{2} \mathrm{e}\end{array}\right|$ & 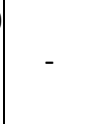 \\
\hline $\begin{array}{l}\text { Normalized } \\
\text { score }\end{array}$ & -52.2 & -72.0 & -50.5 & -50.0 & -48.1 & - \\
\hline $\begin{array}{l}\text { Weighted } \\
\text { score }\end{array}$ & -41.8 & -5.0 & -3.05 & -1.0 & -2.4 & -53.2 \\
\hline Alternative 2 & $\begin{array}{c}325 \\
\text { MSEK }\end{array}$ & $\begin{array}{c}20.1 \\
\text { MSEK }\end{array}$ & $\begin{array}{l}1074 \\
\text { days }\end{array}$ & $\begin{array}{c}483 \\
\text { days }\end{array}$ & $\left|\begin{array}{c}19500 \\
\text { ton } \\
\mathrm{CO}_{2} \mathrm{e}\end{array}\right|$ & 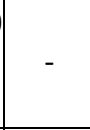 \\
\hline $\begin{array}{l}\text { Normalized } \\
\text { score }\end{array}$ & -47.8 & -28.0 & -49.5 & -50.0 & -51.9 & - \\
\hline $\begin{array}{l}\text { Weighted } \\
\text { score }\end{array}$ & -38.2 & -2.0 & -2.95 & -1.0 & -2.6 & -46.8 \\
\hline
\end{tabular}

Alternative 2 is preferred according to this assessment method. It obtained a better sustainability score as it had a lower initial price and performed better regarding the other KPCS except GWP. The most important KPC is the construction costs; therefore alternative 2 would have been preferred even if it had been up to 25 MSEK more expensive than alternative 1.

\section{Discussion}

By using MCDA, sustainable alternatives have a better chance of being offered to the client as a choice based on a transparent, structured and, to the greatest extent possible, objective evaluation, rather than a subjective and ambiguous evaluation.

In the procurement stage there is limited information available, also limiting the possibility of making a comprehensive MCDA in this stage. The methods used in the case studies were developed considering this, and the data needed for the analysis was available in tender documents.
In that sense, the methods were suitable to use in the procurement stage.

The normalization influences the difference in the weighted sustainability score between the compared alternatives. In the PANTURA method, the normalized score is calculated compared to all available alternatives. In SCORE, the normalized score is calculated compared only to the alternative with the maximum score. Therefore, the difference in normalized scores between alternatives is smaller with the PANTURA method than with SCORE. Thus, the difference in score does not say anything about the difference in sustainability between the alternatives, it only shows that an alternative is more sustainable or less sustainable than another. The difference will affect the weighted sustainability score in a similar way as the weights of the KPCs. It is important to have this in mind, especially when comparing more than two alternatives.

The MCDA methods described in this paper do not fully comply with the EN 15643-5 standard on sustainability assessment of buildings and civil engineering works. They consider mainly local effects and effects in the construction phase, therefore not evaluating the sustainability of alternatives over the whole life cycle and value chain. It is important to use KPCs that are developed based on established knowledge on sustainability of infrastructure projects, as for example the KPCs in "Think Ahead" that were developed based on CEEQUAL. In the case studies, a limited set of KPCs were included.

In general, sustainability assessment results cannot be compared between projects today because results are project specific, e.g. the score of one alternative depends on the scores of the other alternatives considered. In addition, using different MCDA methods can give contradictory results, among others because different normalization methods and KPCs are used.

\section{Conclusion \& recommendations}

MCDA is a well-suited method for sustainability assessment since it meets the EN 15643-5 standard requirements of being credible, transparent and systematic. By using MCDA, choices will be based on an objective evaluation to a greater degree. 
The MCDA methods discussed in this paper are suitable to use for sustainability assessment in the procurement stage, considering the limited information available at that point in time.

However, future sustainability assessments of infrastructure projects should comply with the EN 15643-5 standard fully. This will lead to a more holistic sustainability assessment since the standard includes effects over the whole life cycle and value chain of the infrastructure. It will also enable comparability of the results of assessments of similar projects.

The KPCs in "Think ahead" appear a promising basis for a MCDA method to use for sustainability assessment of infrastructure projects since they are developed based on an established sustainability rating system.

\section{References}

[1] Smith RA, Kersey JR, Griffiths PJ. The Construction Industry Mass Balance: resource use, wastes and emissions (2002).

[2] Spangenberg JH. Design for sustainability (DfS): Interface of sustainable production and consumption. J Clean Prod 2010; 18: 1485-1493.

[3] Bueno PC, Vassallo JM, Cheung K. Sustainability Assessment of Transport Infrastructure Projects: A Review of Existing Tools and Methods. Transp Rev 2015; 35: 622-649.

[4] Belton V, Stewart TJ. Multiple Criteria Decision Analysis - An integrated approach. Kluwer Academic Publishers, 2002.

[5] Huysegoms L, Cappuyns V. Critical review of decision support tools for sustainability assessment of site remediation options. J Environ Manage 2017; 196: 278-296.

[6] Zetterlund $H$, Hallstedt S, Broman G. Implementation Potential of Sustainabilityoriented Decision Support in Product Development. Procedia CIRP 2016; 50: 287-292.

[7] Penadés-Plà V, García-Segura T, Martí J, et al. A Review of Multi-Criteria Decision-Making Methods Applied to the Sustainable Bridge Design. Sustainability 2016; 8: 1295.

[8] Gbededo MA, Liyanage K, Garza-Reyes JA. Towards a Life Cycle Sustainability Analysis: A systematic review of approaches to sustainable manufacturing. J Clean Prod 2018; 184: 1002-1015.
[9] The European Parliament. Directive 2014/24/EU of the European Parliament and of the Council of 26 February 2014 on public procurement and repealing Directive 2004/18/EC (1). Official Journal of the European Union.

[10] Trafikverket (Swedish Transport Administration). Klimatkrav i planläggning, byggskede, underhåll och på teknisk godkänt järnvägsmateriel TDOK 2015:0480 V2.0. 2017.

[11] Kabir G, Sadiq R, Tesfamariam S. A review of multi-criteria decision-making methods for infrastructure management. Struct Infrastruct Eng 2014; 10: 1176-1210.

[12] Mathern A, Larsson T, Claeson-Jonsson C, et al. Performance-based procurement method for urban infrastructure - Appendix C: Decision making from the contractor's side: case study Rotebro. 2013.

[13] Brinkhoff P, Garcao R. Tänk efter före! SBUF report 12870. 2015.

[14] CEEQUAL. CEEQUAL Version 5.1 Assessment manual for projects: International version. 2013.

[15] SIS. SS-EN 15643-5:2017 - Sustainability of construction works - Sustainability assessment of buildings and civil engineering works - Part 5: Framework on specific principles and requirement for civil engineering works. 2017.

[16] Rosén L, Back P-E, Söderqvist $T$, et al. SCORE: A novel multi-criteria decision analysis approach to assessing the sustainability of contaminated land remediation. Sci Total Environ 2015; 511: 621-638.

[17] Sebastian R, Claeson-Jonsson C, Di Giulio R. Performance-based procurement for lowdisturbance bridge construction projects. Constr Innov 2013; 13: 394-409.

[18] SIS. SS-EN ISO 14040:2006 - Environmental management - Life cycle assessment - Principles and framework. 2.

[19] SIS. SS-EN ISO 14044:2006 - Environmental management - Life cycle assessment Requirements and guidelines. 1.

[20] SIS. SS-EN 15804:2012+a1:2013 Sustainability of construction works Environmental product declarations - Core rules for the product category of construction products. [21] International EPD System. Product Category Rules - Construction products and construction services 2012:01, ver 2.2. 